\title{
Enantioselective intramolecular 1,3-dipolar cycloadditions of diazocarbonyl-derived oxidopyryliums
}

\author{
David M. Hodgson, ${ }^{a}{ }^{a}$ Paul A. Stupple, ${ }^{a}$ and Craig Johnstone ${ }^{b}$ \\ ${ }^{a}$ Dyson Perrins Laboratory, Department of Chemistry, University of Oxford, South Parks Road, \\ Oxford, OX1 3QY, UK \\ ${ }^{b}$ AstraZeneca, Mereside, Alderly Park, Macclesfield, Cheshire, SK10 4TG, UK \\ E-mail: david.hodgson@chem.ox.ac.uk
}

Dedicated to Professor A. McKervey on his retirement from Queen's University, Ireland

(received 28 Feb 03; accepted 14 Apr 03; published on the web 18 Apr 03)

\begin{abstract}
Catalytic enantioselective tandem oxidopyrylium formation - intramolecular 1,3-dipolar cycloaddition reactions of phthalic anhydride-derived unsaturated diazocarbonyl compounds in up to $19 \%$ ee are described.
\end{abstract}

Keywords: Asymmetric catalysis, oxidopyryliums, cycloadditions, diazo compounds, rhodium

\section{Introduction}

Compared with enantioselective Diels-Alder and hetero Diels-Alder processes, enantioselective 1,3-dipolar cycloadditions are relatively underdeveloped. ${ }^{1}$ Nevertheless, the latter reaction class holds considerable potential for the asymmetric synthesis of heterocycles. ${ }^{2}$ Studies by Padwa et al. established Rh(II)-catalysed tandem carbonyl ylide formation-1,3-dipolar cycloaddition of diazocarbonyl compounds as an excellent method for the synthesis of oxapolycycles. ${ }^{3}$ In 1997 , using this latter method, we reported the first examples of enantioselective carbonyl ylide cycloadditions: unsaturated 2-diazo-3,6-diketoesters underwent intramolecular cycloaddition catalysed by Davies' prolinate catalyst $\mathrm{Rh}_{2}\left(\mathrm{~S}\right.$-DOSP) ${ }_{4}{ }^{4}$ in up to $52 \%$ ee (Scheme 1, Fig. 1). ${ }^{5}$ $\mathrm{Rh}_{2}$ (S-DOSP) 4 is a fully hydrocarbon soluble version of a prolinate catalyst originally reported during pioneering studies by McKervey on enantioselective transformations of diazocarbonyl compounds using rhodium catalysts. ${ }^{6}$

Cascade reactions such as the example shown in Scheme 1 are of interest because of the rapid generation of molecular complexity, ${ }^{3}$ and because of the demands which it places upon a catalyst - which should both efficiently decompose the diazo precursor and form a catalystassociated ylide (eg, 2), ${ }^{7}$ from which highly (ideally) enantioenriched cycloadduct ensues. The 
latter likely requires that cycloaddition occurs prior to, or simultaneously with, catalyst dissociation from the ylide. Detailed catalyst studies using ester $\mathbf{1}$ eventually led to higher ees of intramolecular cycloadduct 3 using phosphate catalysts, ${ }^{8}$ such as $\operatorname{Pirrung}^{\prime} \mathrm{Rh}_{2}(R \text {-BNP })_{4} ;{ }^{9}$ high levels of asymmetric induction have also been reported by Hashimoto and co-workers in intermolecular carbonyl ylide cycloadditions using 1-diazo-2,5-diketones with DMAD, catalysed by $\mathrm{Rh}(\mathrm{II})$ carboxylates such as $\mathrm{Rh}\left(\mathrm{S}\right.$-PTPA) 4 (Fig. 1). ${ }^{10}$ Enantioselective carbonyl ylide type intermolecular cycloadditions of (aromatic) oxidopyryliums derived from methyl 2(diazoacetyl)benzoate $\left[4, \mathrm{O}\left(\mathrm{CH}_{2}\right)_{2} \mathrm{CH}=\mathrm{CH}_{2}=\mathrm{OMe}\right.$ ] have also been disclosed, ${ }^{11}$ and in the present paper we report some preliminary studies on enantioselective intramolecular cycloadditions of unsaturated oxidopyryliums.

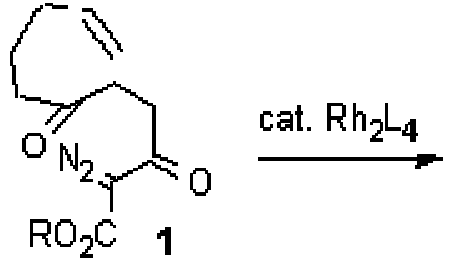

\section{Scheme 1}

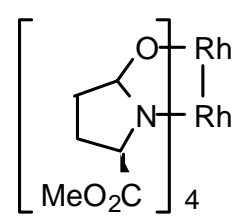

$\mathrm{Rh}_{2}(R-\mathrm{MEPY})_{4}$

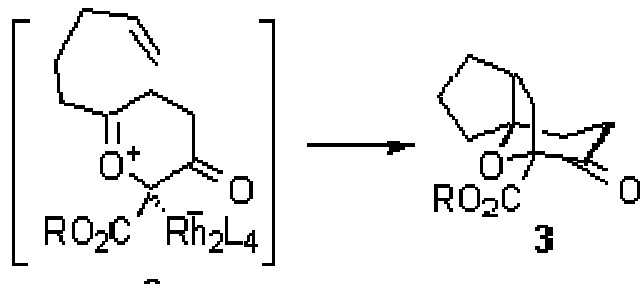

2<smiles></smiles>

$\mathrm{Rh}_{2}(\mathrm{~S}-\mathrm{PTPA})_{4}$<smiles>[R16]c1ccc(OP2Oc3ccc4ccccc4c3-c3c(ccc4ccccc34)CP2c2ccccc2)c(C)c1</smiles><smiles>COC(OC)C(OC)Pc1ccccc1</smiles>

$\mathrm{Rh}_{2}(R-\mathrm{MPA})_{4}$

Figure 1. Chiral Rh(II) catalysts used in the current study.

\section{Results and Discussion}<smiles>C=CCCOC(=O)c1ccccc1C(=O)C=N</smiles>

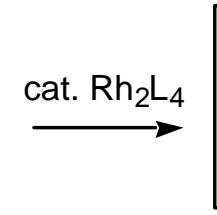<smiles>CCCCOc1[o+]cc(O)c2ccccc12</smiles><smiles>O=C1c2ccccc2[C@]23OCC[C@@H](CC12)O3</smiles>

Scheme 2 
Our initial studies focused on cycloaddition precursor $\mathbf{4}$ as Padwa had already shown that this diazo compound was a viable substrate for tandem oxidopyrylium formation - intramolecular 1,3-dipolar cycloaddition (Scheme 2). ${ }^{12}$ The diazoketoester 4 was screened with representatives of the known classes of chiral rhodium(II) catalysts (Fig. 1), selected for their varying electronic and steric properties and ability to induce enantioselectivity in other diazocarbonyl transformations. ${ }^{3}$ The reactions were carried out in a parallel fashion with purification being simplified by the use of disposable Bond-Elut ${ }^{\circledR}$ prepacked silica cartridges. The isolated cycloadduct 5 was analysed using automated ${ }^{1} \mathrm{H}$ NMR and HPLC systems. These techniques facilitated rapid acquisition of the data set presented in Table 1.

Table 1. Cycloadditions of diazoketoester 4

\begin{tabular}{|c|c|c|c|c|c|}
\hline Entry & Catalyst & Solvent & Temp. & Yield & $E e^{\mathrm{a}}$ \\
\hline 1 & $\mathrm{Rh}_{2}(\mathrm{OAc})_{4}$ & $\mathrm{CH}_{2} \mathrm{Cl}_{2}$ & $25^{\circ} \mathrm{C}$ & $78 \%$ & - \\
\hline 2 & $\mathrm{Rh}_{2}(R-\mathrm{MEPY})_{4}$ & $\mathrm{CH}_{2} \mathrm{Cl}_{2}$ & $25^{\circ} \mathrm{C}$ & $60 \%$ & $\sim 0 \%$ \\
\hline 3 & $\mathrm{Rh}_{2}(R-\mathrm{BNP})_{4}$ & $\mathrm{CH}_{2} \mathrm{Cl}_{2}$ & $25^{\circ} \mathrm{C}$ & $73 \%$ & $\sim 0 \%$ \\
\hline 4 & $\mathrm{Rh}_{2}(R-\mathrm{MPA})_{4}$ & $\mathrm{CH}_{2} \mathrm{Cl}_{2}$ & $25^{\circ} \mathrm{C}$ & $80 \%$ & $\sim 0 \%$ \\
\hline 5 & $\mathrm{Rh}_{2}(R-\mathrm{PTPA})_{4}$ & $\mathrm{CH}_{2} \mathrm{Cl}_{2}$ & $25^{\circ} \mathrm{C}$ & $79 \%$ & $\sim 0 \%$ \\
\hline 6 & $\mathrm{Rh}_{2}(S-\mathrm{DOSP})_{4}$ & $\mathrm{CH}_{2} \mathrm{Cl}_{2}$ & $25^{\circ} \mathrm{C}$ & $85 \%$ & $6 \%(\mathrm{~B})$ \\
\hline 7 & $\mathrm{Rh}_{2}(R-\mathrm{MEPY})_{4}$ & hexane & $25^{\circ} \mathrm{C}$ & $9 \% \mathrm{~b}$ & - \\
\hline 8 & $\mathrm{Rh}_{2}(R-\mathrm{BNP})_{4}$ & hexane & $25^{\circ} \mathrm{C}$ & $16 \% \mathrm{~b}$ & - \\
\hline 9 & $\mathrm{Rh}_{2}(R-\mathrm{MPA})_{4}$ & hexane & $25^{\circ} \mathrm{C}$ & $30 \%$ b & - \\
\hline 10 & $\mathrm{Rh}_{2}(R-\mathrm{PTPA})_{4}$ & hexane & $25^{\circ} \mathrm{C}$ & $43 \% \mathrm{~b}$ & - \\
\hline 11 & $\mathrm{Rh}_{2}(S-\mathrm{DOSP})_{4}$ & hexane & $25^{\circ} \mathrm{C}$ & $32 \%$ & $11 \%(B)$ \\
\hline 12 & $\mathrm{Rh}_{2}(R-\mathrm{MEPY})_{4}$ & $\mathrm{C}_{6} \mathrm{H}_{6}$ & $25^{\circ} \mathrm{C}$ & $31 \%$ & $2 \%(\mathrm{~A})$ \\
\hline 13 & $\mathrm{Rh}_{2}(R-\mathrm{BNP})_{4}$ & $\mathrm{C}_{6} \mathrm{H}_{6}$ & $25^{\circ} \mathrm{C}$ & $50 \%$ & $5 \%(\mathrm{~B})$ \\
\hline 14 & $\mathrm{Rh}_{2}(R-\mathrm{MPA})_{4}$ & $\mathrm{C}_{6} \mathrm{H}_{6}$ & $25^{\circ} \mathrm{C}$ & $93 \%$ & $4 \%(B)$ \\
\hline 15 & $\mathrm{Rh}_{2}(R-\mathrm{PTPA})_{4}$ & $\mathrm{C}_{6} \mathrm{H}_{6}$ & $25^{\circ} \mathrm{C}$ & $95 \%$ & $9 \%(\mathrm{~B})$ \\
\hline 16 & $\mathrm{Rh}_{2}(S-\mathrm{DOSP})_{4}$ & $\mathrm{C}_{6} \mathrm{H}_{6}$ & $25^{\circ} \mathrm{C}$ & $96 \%$ & $16 \%(\mathrm{~B})$ \\
\hline 17 & $\mathrm{Rh}_{2}(R-\mathrm{MEPY})_{4}$ & $\mathrm{C}_{6} \mathrm{H}_{6}$ & $40^{\circ} \mathrm{C}$ & $64 \%$ & $7 \%(\mathrm{~A})$ \\
\hline 18 & $\mathrm{Rh}_{2}(R-\mathrm{BNP})_{4}$ & $\mathrm{C}_{6} \mathrm{H}_{6}$ & $40^{\circ} \mathrm{C}$ & $65 \%$ & $7 \%(\mathrm{~B})$ \\
\hline 19 & $\mathrm{Rh}_{2}(R-\mathrm{MPA})_{4}$ & $\mathrm{C}_{6} \mathrm{H}_{6}$ & $40^{\circ} \mathrm{C}$ & $93 \%$ & $2 \%(B)$ \\
\hline 20 & $\mathrm{Rh}_{2}(R-\mathrm{PTPA})_{4}$ & $\mathrm{C}_{6} \mathrm{H}_{6}$ & $40^{\circ} \mathrm{C}$ & $95 \%$ & $2 \%(\mathrm{~A})$ \\
\hline 21 & $\mathrm{Rh}_{2}(S-\mathrm{DOSP})_{4}$ & $\mathrm{C}_{6} \mathrm{H}_{6}$ & $40^{\circ} \mathrm{C}$ & $90 \%$ & $7 \%(\mathrm{~B})$ \\
\hline 22 & $\mathrm{Rh}_{2}(R-\mathrm{MEPY})_{4}$ & $\mathrm{C}_{6} \mathrm{H}_{6}$ & $7^{\circ} \mathrm{C}$ & $23 \%$ & $4 \%(\mathrm{~A})$ \\
\hline 23 & $\mathrm{Rh}_{2}(R-\mathrm{BNP})_{4}$ & $\mathrm{C}_{6} \mathrm{H}_{6}$ & $7^{\circ} \mathrm{C}$ & $44 \%$ & $15 \%(B)$ \\
\hline 24 & $\mathrm{Rh}_{2}(R-\mathrm{MPA})_{4}$ & $\mathrm{C}_{6} \mathrm{H}_{6}$ & $7^{\circ} \mathrm{C}$ & $50 \%$ & $3 \%(\mathrm{~A})$ \\
\hline 25 & $\mathrm{Rh}_{2}(R-\mathrm{PTPA})_{4}$ & $\mathrm{C}_{6} \mathrm{H}_{6}$ & $7^{\circ} \mathrm{C}$ & $70 \%$ & $2 \%(\mathrm{~A})$ \\
\hline 26 & $\mathrm{Rh}_{2}(S-\mathrm{DOSP})_{4}$ & $\mathrm{C}_{6} \mathrm{H}_{6}$ & $7^{\circ} \mathrm{C}$ & $76 \%$ & $19 \%(\mathrm{~B})$ \\
\hline
\end{tabular}


a "A" refers to the major peak being that which elutes first from Chiralpak AD; "B" refers to the major peak being that which elutes second.

$\mathrm{b}$ Impurities were present which prevented accurate determination of ee. All ees appear to be less than $10 \%$ as judged by HPLC.

$\mathrm{CH}_{2} \mathrm{Cl}_{2}$ was initially used as the solvent, which with each catalyst was found to furnish cycloadduct 5 in good yield, but with no enantioselectivity, aside from $\mathrm{Rh}_{2}(S$-DOSP) 4 (Table 1 , entry $6,6 \% e e$ ). The cycloaddition precursor 4 was found to have only limited solubility in hexane at room temperature, which may account for the low yields of $\mathbf{5}$ that were obtained in this solvent (entries 7-10). Also, complete purification was not possible in these latter cases, which therefore prevented accurate determination of enantioselectivities by HPLC analysis, although the ees appeared to be below $10 \%$. Using $\mathrm{C}_{6} \mathrm{H}_{6}$ as the solvent at room temperature, cycloadduct 5 was isolated in moderate to excellent yields, although once again the level of enantiocontrol was low. The highest level of enantioselectivity in the formation of cycloadduct 5 at room temperature was provided by $\mathrm{Rh}_{2}(S$-DOSP) 4 (entry 16, 16\% ee). Neither increasing the reaction temperature to $40{ }^{\circ} \mathrm{C}$, nor cooling to $7{ }^{\circ} \mathrm{C}$ had a significant effect on the asymmetric induction (the ee with $\mathrm{Rh}_{2}\left(\mathrm{~S}\right.$-DOSP) 4 at $7{ }^{\circ} \mathrm{C}$ was $19 \%$, entry 26); however, the yields generally improved as the reaction temperature was increased.

As we had earlier observed good asymmetric induction in intramolecular cycloaddition with tethered alkenes when using an $\alpha$-diazo- $\beta$-ketoester substrate ( $c f$, Scheme 1 ) we decided to examine oxidopyrylium formation - cycloaddition using a diazoketodiester (Scheme 3). Methyl ester 7 was studied, as this facilitated ee analysis by chiral shift agents. ${ }^{13}$ Methyl ester 7 was efficiently prepared by addition of lithiated methyl diazoacetate to phthalic anhydride ${ }^{14}$ (74\%), followed by esterification of the resulting diazoacid 6 with 3-buten-1-ol using DCC (78\%).
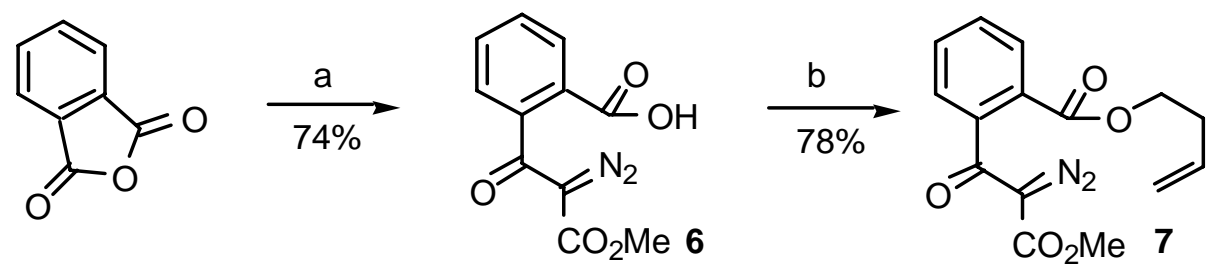

Scheme 3. Reagents and conditions: (a) Methyl diazoacetate, LDA, THF, -78 ${ }^{\circ} \mathrm{C}, 140 \mathrm{~min}$; (b) $\mathrm{CH}_{2}=\mathrm{CH}\left(\mathrm{CH}_{2}\right)_{2} \mathrm{OH}$, DMAP, DCC, THF, $25^{\circ} \mathrm{C}, 15 \mathrm{~h}$.

The tandem cyclisation-cycloaddition of 7 was next investigated using three solvents and using two catalysts, $\mathrm{Rh}_{2}(S \text {-DOSP })_{4}$ and $\mathrm{Rh}_{2}(R \text {-BNP })_{4}$. The results of this survey are presented in Table 2. Reaction of $\mathbf{7}$ under $\mathrm{Rh}_{2}(S$-DOSP) 4 catalysis gave cycloadduct 8 (Scheme 4 ) in good yield using hexane, $\mathrm{CH}_{2} \mathrm{Cl}_{2}$ or $\mathrm{C}_{6} \mathrm{H}_{6}$ as the solvent. However, the enantioselectivity, determined by using the chiral shift agent $\operatorname{Pr}(\mathrm{hfc})_{3}(15 \mathrm{~mol} \%$ ), was found to be small in each case. 
<smiles>C=CCCOC(=O)c1ccccc1C(=O)C(=O)C(=O)OC</smiles>

7

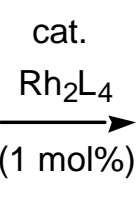

(1 mol\%)

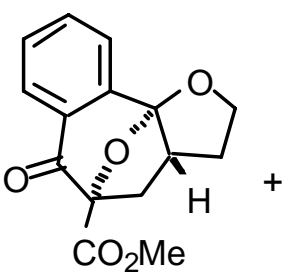

8<smiles>C=CCCOC(=O)C(C(=O)OC)c1ccccc1C(=O)OC</smiles>

9<smiles>C=CCCCCCC</smiles>

10

\section{Scheme 4}

Table 2. Cycloadditions of diazoketodiester 7

\begin{tabular}{cccccccc}
\hline Entry & Catalyst & Solvent & Temp & \multicolumn{3}{c}{ Isolated Yields } & $E e^{\text {a }}$ \\
& & & & 8 & 9 & 10 & of 8 \\
\hline 1 & $\mathrm{Rh}_{2}(S \text {-DOSP })_{4}$ & hexane & $25^{\circ} \mathrm{C}$ & $88 \%$ & $0 \%$ & $0 \%$ & $2 \%$ \\
2 & $\mathrm{Rh}_{2}(S \text {-DOSP })_{4}$ & $\mathrm{CH}_{2} \mathrm{Cl}_{2}$ & $25^{\circ} \mathrm{C}$ & $78 \%$ & $0 \%$ & $0 \%$ & $6 \%$ \\
3 & $\mathrm{Rh}_{2}(S \text {-DOSP })_{4}$ & $\mathrm{C}_{6} \mathrm{H}_{6}$ & $25^{\circ} \mathrm{C}$ & $82 \%$ & $0 \%$ & $0 \%$ & $6 \%$ \\
4 & $\mathrm{Rh}_{2}(R \text {-BNP })_{4}$ & hexane & $25{ }^{\circ} \mathrm{C}$ & $0 \%$ & $25 \%$ & $26 \%$ & - \\
5 & $\mathrm{Rh}_{2}(R-\mathrm{BNP})_{4}$ & $\mathrm{CH}_{2} \mathrm{Cl}_{2}$ & $25{ }^{\circ} \mathrm{C}$ & $41 \%$ & $0 \%$ & $31 \%$ & $0 \%$ \\
6 & $\mathrm{Rh}_{2}(R-\mathrm{BNP})_{4}$ & $\mathrm{C}_{6} \mathrm{H}_{6}$ & $25^{\circ} \mathrm{C}$ & $79 \%$ & $0 \%$ & $0 \%$ & $0 \%$ \\
\hline
\end{tabular}

a Determined by ${ }^{1} \mathrm{H}$ NMR using $(+)-\operatorname{Pr}(\mathrm{hfc}) 3$; the major peak was at higher ppm.

When $\mathrm{Rh}_{2}(R \text {-BNP })_{4}$ was used as the catalyst the chemoselectivity was found to be less predictable. In hexane, cycloadduct $\mathbf{8}$ was not formed, however, triester $\mathbf{9}$ and enol $\mathbf{1 0}$ were isolated (Scheme 4). Triester $\mathbf{9}$ could result from Wolff rearrangement of the putative intermediate metallocarbene $\mathbf{1 1}$ arising from diazoketodiester $\mathbf{7}$ (Scheme 5), followed by addition to the resulting ketene $\mathbf{1 2}$ of 3-buten-1-ol which is released during the formation of enol $\mathbf{1 0}$.

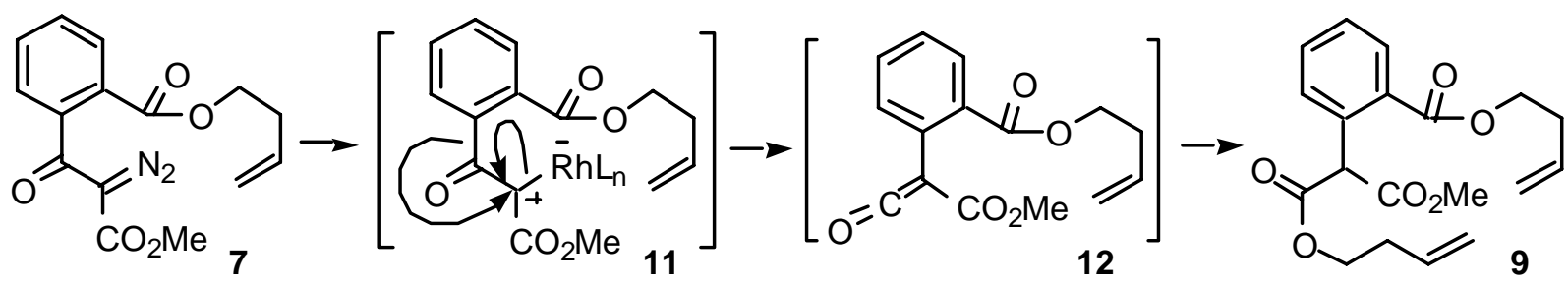

\section{Scheme 5}

Enol 10 may originate from addition of traces of water present in the reaction mixture to the intermediate oxidopyrylium 13 formed from 7, followed by loss of 3-buten-1-ol (Scheme 6). 


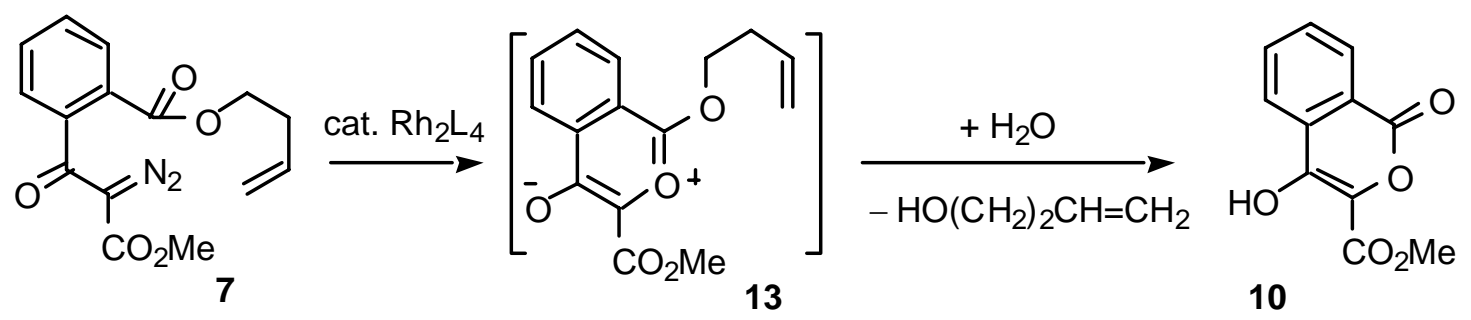

\section{Scheme 6}

Using either $\mathrm{CH}_{2} \mathrm{Cl}_{2}$ or $\mathrm{C}_{6} \mathrm{H}_{6}$ as the solvent with $\mathrm{Rh}_{2}(R-\mathrm{BNP})_{4}$ afforded cycloadduct $\mathbf{8}$, however, both samples were found to be racemic. The remarkably different product profile observed using hexane may originate from the low level of solubility of $\mathrm{Rh}_{2}(R-\mathrm{BNP})_{4}$ in this solvent. In both $\mathrm{CH}_{2} \mathrm{Cl}_{2}$ and $\mathrm{C}_{6} \mathrm{H}_{6}$ the catalyst was found to be particularly soluble as indicated by the formation of green solutions after addition of the Rh(II) complex, rather than the suspension that was observed in hexane.

In conclusion, this paper reports the first studies on asymmetric intramolecular cycloadditions of unsaturated oxidopyryliums. The low levels of enantioinduction obtained show that such cycloadditions are possible in an enantioselective manner, although the extent of their potential remains to be established. Comparison with Hashimoto's studies of intermolecular oxidopyrylium cycloadditions with highly electron deficient dipolarophiles such as DMAD 11 suggests the nature of the dipolarophile plays a crucial role in enantioselectivity.

\section{Experimental Section}

General Procedures. Reactions were carried out under an argon atmosphere in oven dried apparatus, where appropriate. Syringes and needles were oven dried and cooled in a desiccator over self-indicating silica gel or $\mathrm{P}_{2} \mathrm{O}_{5}$ prior to use. Anhydrous THF was obtained by distillation from sodium benzophenone ketyl under argon. Anhydrous $\mathrm{C}_{6} \mathrm{H}_{6}$ and $\mathrm{CH}_{2} \mathrm{Cl}_{2}$ were obtained by distillation from $\mathrm{CaH}_{2}$ under argon. Hexane was stored over molecular sieves for at least $24 \mathrm{~h}$ prior to use. 'Petrol' refers to that fraction of light petroleum ether boiling in the range $40-60{ }^{\circ} \mathrm{C}$. Reaction temperatures are reported as internal, unless otherwise stated. Thin layer chromatography (TLC) was carried out on glass backed plates precoated with $0.25 \mathrm{~mm}$ Merck silica gel 60 F-254 and were visualised by the quenching of UV fluorescence (254 nm) and staining with $\mathrm{KMnO}_{4}$, vanillin or $5 \%$ (w/v) dodeca-molybdophosphoric acid in EtOH followed by heat. Column chromatography was carried out on Kieselgel 60 (40-63 $\mu \mathrm{m})$, Sorbsil C60 40/60 silica or Bond-Elut ${ }^{\circledR}$ cartridges (silica, $10 \mathrm{~g}$ ). Solvents were removed using a Büchi rotary evaporator under reduced pressure, remaining solvent residues were removed using a static oil pump ( 1 mmHg), where appropriate. ${ }^{1} \mathrm{H}$ NMR $\left(\delta_{\mathrm{H}}\right)$ and ${ }^{13} \mathrm{C}$ NMR $\left(\delta_{\mathrm{C}}\right)$ spectra were recorded using a Bruker AC 200, a Varian Gemini 200, or a Bruker DPX 400 spectrometer in $\mathrm{CDCl}_{3}$, 
unless otherwise stated. Chemical shifts are reported in parts per million (ppm) relative to the internal $\mathrm{CDCl}_{3}$ lock. Coupling constants $(J)$ are reported in Hz. A combination of DEPT 135, DEPT 90, DEPT 45, HMQC, HMBC and COSY experiments were used to aid spectral interpretation. IR spectra $\left(v_{\max }\right)$ were recorded as thin films using $\mathrm{NaCl}$ plates or $\mathrm{KBr}$ discs using a Perkin-Elmer 1750 FT-IR spectrometer or a Perkin-Elmer Paragon 1000 FT-IR spectrometer. Peak intensities are specified as strong (s), medium (m), weak (w) or shoulder (sh). Melting points are uncorrected and were obtained using a Griffin Melting Point Apparatus, recrystallisation solvents (where appropriate) are indicated in parentheses. Mass spectra were recorded on a VG Micromass ZAB 1F, a Masslab 20-250, a VG TRIO-1 or a VG Platform 1 machine. High resolution mass spectra were obtained from the EPSRC Mass Spectrometry Service Centre, Swansea. $\mathrm{m} / \mathrm{z}$ values are reported in Daltons and are followed by their percentage abundancies in parentheses. Microanalyses were performed by the Analytical Services Department at the Inorganic Chemistry Laboratory, Oxford, using an elemental analyser Vario EL. Enantiomeric excess was determined by ${ }^{1} \mathrm{H}$ NMR with the addition of the chiral shift agent (+)-Pr(hfc)3. Alternatively, chiral stationary phase HPLC was performed using a Daicel Chiralpak AD column ( $4.6 \mathrm{~mm}$ x $250 \mathrm{~mm}$ ) on a Gilson system with 712 Controller Software and a $118 \mathrm{UV} /$ vis detector set at $254 \mathrm{~nm}$. Retention times for major $\left(t_{\mathrm{R}} \mathrm{mj}\right)$ and minor $\left(t_{\mathrm{R}} \mathrm{mn}\right)$ enantiomers are given in minutes.

9,10-Benzo-2,11-dioxa-tricyclo[5.3.1.01,5] undecan-8-one (5). ${ }^{12}$ General procedure: To a stirred solution of the diazoketone $4^{12}$ (approx. $100 \mathrm{mg}, 0.46 \mathrm{mmol}$ ) in solvent $(10 \mathrm{ml}$ ) at the desired temperature was added a $\mathrm{Rh}(\mathrm{II})$ catalyst $(1 \mathrm{~mol} \%)$. When TLC analysis indicated complete consumption of starting material, the reaction mixture was either concentrated in vacuo $\left(\mathrm{CH}_{2} \mathrm{Cl}_{2}\right)$ or transferred directly $\left(\mathrm{C}_{6} \mathrm{H}_{6}\right.$ and hexane) onto a silica Bond Elut ${ }^{\circledR}(10 \mathrm{~g} ; 5: 1$ petrol:Et $\left.{ }_{2} \mathrm{O}\right)$ to give the title compound as a white solid. $\mathrm{R}_{\mathrm{f}} 0.25$ (1:1 petrol:Et $\left.2 \mathrm{O}\right) ; v_{\max } / \mathrm{cm}^{-1}$ $(\mathrm{KBr}) 2964 \mathrm{w}(\mathrm{CH}), 1698 \mathrm{~s}(\mathrm{C}=\mathrm{O}), 1600 \mathrm{~m}, 1288 \mathrm{~s}, 1041 \mathrm{~s}, 1004 \mathrm{~m} ; \delta_{\mathrm{H}}(200 \mathrm{MHz}) 1.90-2.12(1 \mathrm{H}$, m), 2.16 (1 H, m), 2.28-2.50 (2 H, m), 2.60-2.70 (1 H, m), 4.35-4.60 (2 H, m, C(3)H $)$, 4.91 (1 H, d, J 8.0, C(7)H), 7.42-7.52 (1 H, m, C(Ar)H), 7.57-7.62 (2 H, m, 2 x C(Ar)H), 7.99 (1H, dd, $J$ = 7.5, $1.5 \mathrm{~Hz}, \mathrm{C}(\mathrm{Ar}) \mathrm{H}$ ). Ee determined by HPLC (Chiralpak AD, 60:40 hexane:EtOH, 0.5 $\mathrm{ml} / \mathrm{min}, 0.5 \mathrm{mg} / \mathrm{ml}$ ), $t_{\mathrm{R}} \mathrm{mn}, 12.9 ; t_{\mathrm{R}} \mathrm{mj}, 19.0$ (obtained from reaction using $\mathrm{Rh}_{2}\left(S\right.$-DOSP) ${ }_{4}$ in $\mathrm{C}_{6} \mathrm{H}_{6}$ ).

Methyl 3-(2-carboxyphenyl)-2-diazo-3-oxopropanoate (6). A stirred solution of $\left(\mathrm{Pr}^{\mathrm{i}}\right)_{2} \mathrm{NH}$ (6.04 ml, $4.31 \mathrm{mmol})$ in THF $(120 \mathrm{ml})$ was cooled to $-78^{\circ} \mathrm{C}$ before dropwise addition of $\mathrm{Bu}^{\mathrm{n}} \mathrm{Li}$ (17.8 $\mathrm{ml}$ of a $2.3 \mathrm{M}$ solution in hexanes). After $0.5 \mathrm{~h}$ the LDA was added dropwise over $20 \mathrm{~min}$, via cannula, to a solution of methyl diazoacetate $\left(4.41 \mathrm{~g}\right.$ of $93 \%(\mathrm{w} / \mathrm{w})$ mixture with $\mathrm{CH}_{2} \mathrm{Cl}_{2}$, $4.10 \mathrm{mmol}$, CAUTION: chilled glassware and blast shields were used in the preparation of methyl diazoacetate, ${ }^{15}$ due to the reported potential for explosions) and recrystallised $\left(\mathrm{CHCl}_{3}\right)$ phthalic anhydride $(5.51 \mathrm{~g}, 37.2 \mathrm{mmol})$ in THF $(150 \mathrm{ml})$ at $-78{ }^{\circ} \mathrm{C}$. After $2 \mathrm{~h}$ glacial acetic acid $(2.6 \mathrm{ml})$ was added and the reaction mixture allowed to warm to room temperature. The solution was concentrated in vacuo until the volume was approx. $50 \mathrm{ml}$ before $2 \mathrm{M} \mathrm{HCl}(5 \mathrm{ml})$ and $\mathrm{H}_{2} \mathrm{O}$ 
$(45 \mathrm{ml})$ were added. The aqueous phase was separated and extracted with $\mathrm{Et}_{2} \mathrm{O}$ ( $\left.3 \mathrm{x} 50 \mathrm{ml}\right)$. The combined organic layers were extracted with sat. aq. $\mathrm{NaHCO}_{3}(50 \mathrm{ml})$ and $\mathrm{H}_{2} \mathrm{O}(10 \mathrm{ml})$. The combined aqueous layers were acidified with $2 \mathrm{M} \mathrm{HCl}$, extracted with $\mathrm{CH}_{2} \mathrm{Cl}_{2}(3 \mathrm{x} 100 \mathrm{ml})$ and concentrated in vacuo. The residue was purified by column chromatography (19:1 $\left.\mathrm{CH}_{2} \mathrm{Cl}_{2}: \mathrm{MeOH}\right)$ to give the title compound as a pale yellow foam $(6.85 \mathrm{~g}, 74 \%) . \mathrm{R}_{\mathrm{f}} 0.42$ (9:1 $\left.\mathrm{CH}_{2} \mathrm{Cl}_{2}: \mathrm{MeOH}\right) ; \mathrm{mp} 71-72{ }^{\circ} \mathrm{C} ; v_{\max } / \mathrm{cm}^{-1}(\mathrm{KBr}) 2960 \mathrm{w}$,br $(\mathrm{OH}), 2136 \mathrm{~m}\left(\mathrm{CN}_{2}\right), 1725 \mathrm{~s}(\mathrm{C}=\mathrm{O})$, 1637w (C=C), 1340m, 1263m; $\delta_{\mathrm{H}}(200 \mathrm{MHz}) 3.70$ (3 H, s, $\left.\mathrm{CH}_{3}\right), 7.28(1 \mathrm{H}, \mathrm{d}, J$ 2.0, C(Ar)H), 7.32-7.66 (2 H, m, 2 x C(Ar)H), 8.13 (1 H, d, J 7.5, C(Ar)H), 10.52 (1 H, s, br, CO $2 \mathrm{H}) ; \delta_{\mathrm{C}}(50.3$ MHz) $52.2\left(\mathrm{CH}_{3}\right), 76.8\left(\mathrm{CN}_{2}\right), 126.4,129.7,130.5$ and $133.2(4 \mathrm{x} \mathrm{CH}), 127.0$ and $141.2(2 \mathrm{x}$ quat.), $161.1\left(\mathrm{CO}_{2} \mathrm{CH}_{3}\right), 170.3\left(\mathrm{CO}_{2} \mathrm{H}\right), 188.7(\mathrm{C}=\mathrm{O}) ; \mathrm{m} / \mathrm{z}(\mathrm{CI}+) 266\left(\mathrm{MNH}_{4}^{+}, 30 \%\right), 249\left(\mathrm{MH}^{+}\right.$, 12), 240 (100), 238 (70), 166 (83), 152 (70), 121 (71), 105 (90) (Found $\mathrm{MH}^{+}, 249.0509$. $\mathrm{C}_{11} \mathrm{H}_{9} \mathrm{~N}_{2} \mathrm{O}_{5}$ requires 249.05115).

Methyl 3-[(but-3-enyl) 2-phenylcarboxylate]-2-diazo-3-oxopropanoate (7). To a stirred solution of diazoacid 6 (2.59 g, $10.44 \mathrm{mmol})$, 3-buten-1-ol (0.89 ml, $10.44 \mathrm{mmol})$ and DMAP (180 mg, $1.48 \mathrm{mmol})$ in THF $(50 \mathrm{ml})$ at room temperature was added DCC (2.37 $\mathrm{g}, 11.48$ mmol). After $15 \mathrm{~h}$ the precipitate was filtered off, washed with $\mathrm{Et}_{2} \mathrm{O}(10 \mathrm{ml})$ and the filtrate diluted with a second portion of $\mathrm{Et}_{2} \mathrm{O}(50 \mathrm{ml})$. The combined organic layers were washed with sat. aq. $\mathrm{NaHCO}_{3}(30 \mathrm{ml})$ and concentrated in vacuo. The residue was purified by column chromatography (5:1 petrol:Et ${ }_{2} \mathrm{O}$ ) to give the title compound as a yellow oil (2.47 $\mathrm{g}, 78 \%$ ). $\mathrm{R}_{\mathrm{f}}$ 0.46 (1:1 petrol:Et $2 \mathrm{O}$ ); $v_{\text {max }} / \mathrm{cm}^{-1}$ (thin film) 2133m $\left(\mathrm{CN}_{2}\right), 1724 \mathrm{~s}(\mathrm{C}=\mathrm{O}), 1642 \mathrm{~m}, 1337 \mathrm{~m}$, $1278 \mathrm{~m}, 1127 \mathrm{~m} ; \delta_{\mathrm{H}}(200 \mathrm{MHz}) 2.43-2.53\left(2 \mathrm{H}, \mathrm{m}, \mathrm{CH}_{2} \mathrm{CH}=\mathrm{CH}_{2}\right), 3.68\left(3 \mathrm{H}, \mathrm{s}, \mathrm{CH}_{3}\right), 4.32(2 \mathrm{H}$, t, $J$ 6.5, $\left.\mathrm{OCH}_{2}\right), 5.08-5.20\left(2 \mathrm{H}, \mathrm{m}, \mathrm{CH}=\mathrm{CH}_{2}\right), 5.83\left(1 \mathrm{H}\right.$, ddt, $J$ 17.0, 10.5 and 6.5, $\mathrm{CH}=\mathrm{CH}_{2}$ ), 7.26 (1 H, d, J 2.0, C(Ar)H), 7.29-7.64 (2 H, m, 2 x C(Ar)H), $8.03\left(1 \mathrm{H}, \mathrm{d}, J\right.$ 7.5, C(Ar)H); $\delta_{\mathrm{C}}$ (50.3 MHz) $32.7\left(\mathrm{CH}_{2} \mathrm{CH}=\mathrm{CH}_{2}\right), 52.0\left(\mathrm{CH}_{3}\right), 64.4\left(\mathrm{CO}_{2} \mathrm{CH}_{2}\right), 76.4\left(\mathrm{CN}_{2}\right), 117.4\left(\mathrm{CH}=\mathrm{CH}_{2}\right)$, 126.4, 129.7, 129.9, 132.6 and 134.0 (5 x CH), 128.2 and 141.1 (2 x quat.), 161.2 and 165.8 (2 x $\left.\mathrm{CO}_{2}\right), 188.7(\mathrm{C}=\mathrm{O}) ; \mathrm{m} / \mathrm{z}(\mathrm{CI}+) 320\left(\mathrm{MNH}_{4}^{+}, 100 \%\right), 303\left(\mathrm{MH}^{+}, 31\right), 294$ (42), 292 (31), 275 (68), 70 (60) (Found $\mathrm{MH}^{+}$, 303.0975. $\mathrm{C}_{15} \mathrm{H}_{15} \mathrm{~N}_{2} \mathrm{O}_{5}$ requires 303.09810).

\section{9,10-Benzo-7-carbomethoxy-2,11-dioxa-tricyclo[5.3.1.01,5] undecan-8-one (8).}

General procedure: To a stirred solution of the diazoketodiester 7 (approx. $100 \mathrm{mg}, 0.33 \mathrm{mmol}$ ) in solvent $(10 \mathrm{ml})$ at the desired temperature was added a Rh(II) catalyst (0.5-1.0 mol\%). When TLC analysis indicated complete consumption of starting material the reaction mixture was either concentrated in vacuo $\left(\mathrm{CH}_{2} \mathrm{Cl}_{2}\right)$ or transferred directly $\left(\mathrm{C}_{6} \mathrm{H}_{6}\right.$ or hexane) onto a silica Bond-Elut ${ }^{\circledR}$ (10 g; 5:1 petrol:Et ${ }_{2} \mathrm{O}$ ). The title compound 8 was isolated as a white solid, which could be further purified by recrystallisation from cyclohexane. $\mathrm{R}_{\mathrm{f}} 0.28$ (1:1 petrol:Et $2 \mathrm{O}$ ); mp 109-110 ${ }^{\circ} \mathrm{C}$ (cyclohexane); (Found: C, 65.61; H, 5.17. $\mathrm{C}_{15} \mathrm{H}_{14} \mathrm{O}_{5}$ requires $\mathrm{C}, 65.69 ; \mathrm{H}, 5.14 \%$ ); $v_{\max } / \mathrm{cm}^{-1}(\mathrm{KBr}) 1749 \mathrm{~s}(\mathrm{C}=\mathrm{O}), 1700 \mathrm{~s}(\mathrm{C}=\mathrm{O}), 1601 \mathrm{w}, 1324 \mathrm{w}, 1285 \mathrm{w}, 1080 \mathrm{~s} ; \delta_{\mathrm{H}}(400 \mathrm{MHz})$ 1.97-2.06 (1 H, m, C(4)Ha $\left.H_{\mathrm{b}}\right), 2.42\left(1 \mathrm{H}, \mathrm{dd}, J 14.2\right.$ and 8.6, C(6) $\left.\mathrm{H}_{a} \mathrm{H}_{\mathrm{b}}\right), 2.41-2.48(1 \mathrm{H}, \mathrm{m}$, $\left.\mathrm{C}(4) \mathrm{H}_{\mathrm{a}} \mathrm{H}_{\mathrm{b}}\right), 2.64$ (1 H, dd, J 14.2 and 3.8, C(6) $\left.\mathrm{H}_{\mathrm{a}} \mathrm{H}_{\mathrm{b}}\right), 2.68-2.76(1 \mathrm{H}, \mathrm{m}, \mathrm{C}(5) \mathrm{H}), 3.88$ (3 H, s, $\left.\mathrm{OCH}_{3}\right), 4.39-4.45$ (1 H, m, C(3) $\left.\mathrm{H}_{\mathrm{a}} \mathrm{H}_{\mathrm{b}}\right), 4.58$ (1 H, ddd, $J$ 14.0, 8.6 and5.4, C(3) $\left.\mathrm{H}_{\mathrm{a}} \mathrm{H}_{\mathrm{b}}\right), 7.47-7.51$ $(1 \mathrm{H}, \mathrm{m}, \mathrm{C}(\mathrm{Ar}) \mathrm{H}), 7.59-7.66$ (2 H, m, 2 x C(Ar)H), 8.01 (1 H, d, J 7.7, CHCC(O)); $\delta_{\mathrm{C}}(100$ 
MHz) $33.1\left(\mathrm{C}(4) \mathrm{H}_{2}\right), 35.4\left(\mathrm{C}(6) \mathrm{H}_{2}\right), 47.3(\mathrm{C}(5) \mathrm{H}), 53.0\left(\mathrm{OCH}_{3}\right), 72.3\left(\mathrm{C}(3) \mathrm{H}_{2}\right), 90.4$ and 114.8 (2 x quat.), 122.1, 127.7, 129.0 and 134.5 (4 x C(Ar)H), 128.8 and 143.9 (2 x quat.(Ar)), 167.3 $\left(\mathrm{CO}_{2}\right), 191.5(\mathrm{C}=\mathrm{O}) ; \mathrm{m} / \mathrm{z}(\mathrm{APCI}+) 297\left(\mathrm{M}+\mathrm{Na}^{+}, 11 \%\right), 275\left(\mathrm{MH}^{+}, 100\right), 257$ (10). Ee determined by comparison of split singlet ( $\delta 3.88$ ) integrals in $200 \mathrm{MHz}{ }^{1} \mathrm{H}$ NMR spectrum using 0.10 equiv. $\operatorname{Pr}(\mathrm{hfc})_{3}$.

(But-3-enyl) methyl 2-((but-3-enyl) 2-phenylcarboxylate)-malonate (9) was isolated as a colourless oil. $\mathrm{R}_{\mathrm{f}} 0.42$ (1:1 petrol:Et $2 \mathrm{O}$ ); $v_{\max } / \mathrm{cm}^{-1}$ (thin film) 2956w (CH), 1750s (C=O), $1735 \mathrm{~s}$ $(\mathrm{C}=\mathrm{O}), 1714 \mathrm{~s}(\mathrm{C}=\mathrm{O}), 1256 \mathrm{~m}, 1143 \mathrm{~m} ; \delta_{\mathrm{H}}(400 \mathrm{MHz}) 2.44\left(2 \mathrm{H}, \mathrm{q}, J\right.$ 6.7, $\left.\mathrm{CH}_{2} \mathrm{CH}=\mathrm{CH}_{2}\right), 2.56(2$ $\mathrm{H}, \mathrm{q}, J$ 6.7, $\left.\mathrm{CH}_{2} \mathrm{CH}=\mathrm{CH}_{2}\right), 3.82\left(3 \mathrm{H}, \mathrm{s}, \mathrm{CH}_{3}\right), 4.26-4.31\left(2 \mathrm{H}, \mathrm{m}, \mathrm{OCH}_{2}\right), 4.40(2 \mathrm{H}, \mathrm{t}, J$ 6.7, $\left.\mathrm{OCH}_{2}\right)$, 5.08-5.24 (4 H, m, $\left.2 \times \mathrm{CH}=\mathrm{CH}_{2}\right), 5.78\left(1 \mathrm{H}\right.$, ddt, $J$ 17.0, 10.3 and 6.7, $\left.\mathrm{CH}=\mathrm{CH}_{2}\right), 5.82$ $(1 \mathrm{H}, \mathrm{s}, \mathrm{C}(=\mathrm{O}) \mathrm{CH}), 5.90\left(1 \mathrm{H}, \mathrm{ddt}, J\right.$ 17.0, 10.3 and 6.7, $\left.\mathrm{CH}=\mathrm{CH}_{2}\right), 7.44-7.49(2 \mathrm{H}, \mathrm{m}, 2 \mathrm{x}$ $\mathrm{C}(\mathrm{Ar}) \mathrm{H})$, 7.57-7.61 (1 H, m, C(Ar)H), $8.06\left(1 \mathrm{H}, \mathrm{dd}, J 7.8\right.$ and 1.1, C(Ar)H); $\delta_{\mathrm{C}}(100 \mathrm{MHz}) 32.8$ and $33.0\left(2 \times \mathrm{CH}_{2} \mathrm{CH}=\mathrm{CH}_{2}\right), 52.7\left(\mathrm{CH}_{3}\right), 54.8(\mathrm{CHC}(=\mathrm{O})), 64.3$ and $64.8\left(2 \times \mathrm{OCH}_{2}\right), 117.3$ and $117.5\left(2 \times \mathrm{CH}=\mathrm{CH}_{2}\right), 128.0(\mathrm{C}(\mathrm{Ar}) \mathrm{H}), 129.6$ (quat.(Ar), 130.0, 131.0 and $132.4(3 \times \mathrm{C}(\mathrm{Ar}) \mathrm{H})$, 129.6 (quat.(Ar)), 133.6 and $133.9\left(2 \times \mathrm{CH}=\mathrm{CH}_{2}\right), 166.8,168.4$ and $169.0\left(3 \times \mathrm{CO}_{2}\right) ; \mathrm{m} / \mathrm{z}(\mathrm{CI}+)$ $364\left(\mathrm{MNH}_{4}{ }^{+}, 42 \%\right), 347\left(\mathrm{MH}^{+}, 69\right), 118$ (43), 72 (98), 70 (100) (Found $\mathrm{M}^{+}, 346.1415$. $\mathrm{C}_{19} \mathrm{H}_{22} \mathrm{O}_{6}$ requires 346.14164$)$.

Methyl 4-hydroxy-1-oxo-1H-isochromene-3-carboxylate (10) was isolated as a white solid. $\mathrm{R}_{\mathrm{f}}$ 0.37 (1:1 petrol:Et $2 \mathrm{O}$ ); mp $153-155^{\circ} \mathrm{C} ; v_{\max } / \mathrm{cm}^{-1}(\mathrm{KBr}) 1732 \mathrm{~s}(\mathrm{C}=\mathrm{O}), 1668 \mathrm{~m}, 1652 \mathrm{~m}, 1463 \mathrm{~m}$, $1298 \mathrm{~m} ; \delta_{\mathrm{H}}(400 \mathrm{MHz}) 4.01\left(3 \mathrm{H}, \mathrm{s}, \mathrm{CH}_{3}\right), 7.73-7.77(1 \mathrm{H}, \mathrm{m}, \mathrm{CH}), 7.87-7.91(1 \mathrm{H}, \mathrm{m}, \mathrm{CH}), 8.08$ $\left(1 \mathrm{H}, \mathrm{dd}, J 8.0\right.$ and 0.6, CH), $8.36(1 \mathrm{H}, \mathrm{dd}, J 8.0$ and $0.5, \mathrm{CH}), 10.55(1 \mathrm{H}, \mathrm{s}, \mathrm{OH}) ; \delta_{\mathrm{C}}(100$ MHz) $52.9\left(\mathrm{CH}_{3}\right), 123.4,130.1,131.8,134.9$ (4 x CH), 123.9, 124.0, 131.5, 148.1 (4 x quat.),

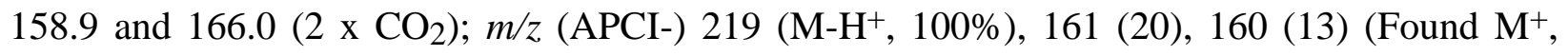
220.0373. $\mathrm{C}_{11} \mathrm{H}_{8} \mathrm{O}_{5}$ requires 220.03717).

\section{Acknowledgments}

We thank AstraZeneca for support of this work, St. Hugh's College for a Jubilee Scholarship (to P. A. S.), and the EPSRC National Mass Spectrometry Service Centre for mass spectra. We are also grateful to Professor M. C. Pirrung (Duke University) for an initial test sample of $\mathrm{Rh}_{2}(S-$ $\mathrm{BNP})_{4}$ and Dr I. Nash (AstraZeneca) for useful discussions.

\section{References}

1. Kobayashi, S.; Jørgensen, K. A., Eds.; Cycloaddition Reactions in Organic Synthesis; WileyVCH: Weinheim, 2002. 
2. Padwa, A.; Pearson, W. H., Eds.; Synthetic Applications of 1,3-Dipolar Cycloaddition Chemistry Toward Heterocycles and Natural Products; John Wiley \& Sons: New York, 2002.

3. (a) Padwa, A.; Weingarten, M. D. Chem. Rev. 1996, 96, 223. (b) Doyle, M. P.; McKervey, M. A.; Ye, T. Modern Catalytic Methods for Organic Synthesis with Diazo Compounds; John Wiley \& Sons: New York, 1998; Ch. 7. (c) Clark, J. S. Nitrogen, Oxygen and Sulfur lide Chemistry; Oxford University Press: Oxford, 2002. (d) Mehta, G.; Muthusamy, S. Tetrahedron 2002, 58, 9477.

4. Davies, H. M. L. Eur. J. Org. Chem. 1999, 2459.

5. Hodgson, D. M.; Stupple, P. A.; Johnstone, C. Tetrahedron Lett. 1997, 38, 6471.

6. Kennedy, M.; McKervey, M. A.; Maguire A. R.; Roos, G. H. P. J. Chem. Soc. Chem. Commun. 1990, 361.

7. (a) Hodgson, D. M.; Pierard, F. Y. T. M.; Stupple, P. A. Chem. Soc. Rev. 2001, 30, 50. (b) Hodgson, D. M.; Stupple, P. A.; Forbes, D. C. In Rodd's Chemistry of Carbon Compounds, Topical Volume, Asymmetric Catalysis; Sainsbury, M., Ed.; Elsevier: Oxford, 2001; p 65. (c) Kitagaki, S.; Hashimoto, S. J. Synth. Org. Chem. Jpn. 2001, 59, 1157.

8. Hodgson, D. M.; Stupple, P. A.; Pierard, F. Y. T. M.; Labande, A. H.; Johnstone, C. Chem. Eur. J. 2001, 7, 4465. See also: Hodgson, D. M.; Labande, A. H.; Pierard, F. Y. T. M. Synlett 2003, 59.

9. Pirrung, M. C.; Zhang, J. Tetrahedron Lett. 1992, 33, 5987. For a related chiral Rh(II) phosphate catalyst reported contemporaneously by McKervey, see: McCarthy, N.; McKervey, M. A.; Ye, T.; McCann, M.; Murphy, E.; Doyle, M. P. Tetrahedron Lett. 1992, 33, 5983.

10. Kitagaki, S.; Masahiro, A.; Kataoka, O.; Matsuno, K.; Umeda, C.; Watanabe, N.; Hashimoto, S. J. Am. Chem. Soc. 1999, 121, 1417.

11. Kitagaki, S.; Yasugahira, M.; Anada, M.; Nakajima, M.; Hashimoto, S. Tetrahedron Lett. 2000, 41, 5931 (up to 93\% ee using DMAD); Suga, H.; Inoue, K.; Inoue, S.; Kakehi, A. J. Am. Chem. Soc. 2002, 124, 14836 (up to 98\% ee using an 3-acryloyl-2-oxazolidinone with a chiral Lewis acid-Rh catalyst combination).

12. Padwa, A.; Carter, S. P.; Nimmesgern, H.; Stull, P. D. J. Am. Chem. Soc. 1988, 110, 2894.

13. No satisfactory analytical method could be found for resolving the cycloadduct from corresponding ethyl ester.

14. Moody, C. J.; Taylor, R. J. J. Chem. Soc., Perkin Trans. 1 1989, 721.

15. Searle, N. E. Org. Synth. 1963, Coll. Vol. IV, 424. 